\title{
Superplastic Blow Forming of Welded Sandwich Panel for Elevated Temperature Application
}

\author{
K.J. Min, J.H. Yoon, J.T. Yoo \\ Korea Aerospace Research Institute \\ 45 Eoun-dong, Yuseong-gu, Daejeon 305-333, Korea
}

\author{
H.H. Jung, Y.R. Lee \\ Department of Space Launch Vehicle System Engineering \\ University of Science \& Technology \\ 217 Gajung-dong Yuseong-gu, Daejeon 305-350, Korea
}

\author{
H.S. Lee \\ Korea Aerospace Research Institute \\ 45 Eoun-dong, Yuseong-gu, Daejeon 305-333, Korea \\ Department of Space Launch Vehicle System Engineering University of Science \& Technology \\ 217 Gajung-dong Yuseong-gu, Daejeon 305-350, Korea
}

\begin{abstract}
Aerospace structure requires lightweight panels to obtain weight saving and strength. It is well known that lightweight and stiff, sandwich panels are one of a vital element of aerospace structural design. In sandwich structures, the face sheets are the main load-bearing element. Since conventional polymer matrix composite materials have a limitation for elevated temperature application, metallic sandwich structures must be used in for elevated temperature application, like propulsion system. In this study, it is demonstrated that superplastic blow forming process with titanium and IN718 can be applied to manufacturing of metallic sandwich structure with cores for lightweight structure of aircraft structural panels and propulsion components. The result shows that the developed technology to process design of gas blow forming by the finite element method can be applied for near net shape forming of various sandwich structures from pre-welded panels.
\end{abstract}

Keywords-manufacturing; sandwich; aerospace; high temperature; propulsion; titanium

\section{INTRODUCTION}

Aerospace vehicles must be lightweight in order to reduce associated fuel costs and increase the carrying payload. Sandwich structures consist of a pair of thin stiff, strong skins and lightweight cores to separate the skins and carry loads from one skin to the other. The lightweight internal core will provide the required resistance to shear and is strong enough to stabilize the skin sheets. The core provides buckling resistance for the structure while at the same time transmitting shear forces. In addition, sandwich structures show inherently remarkable stiffness, vibration damping, thermal, acoustic, and insulation properties.

The application of sandwich structures for use at high temperature depends on the properties of the materials and type of welding method used to manufacture the internal cores. Ti-6Al-4V is useful materials in aerospace applications due to their high strength and stiffness, good corrosion resistance and low density. It is one of the commonly used alloys in aerospace airframe and engine component and is used in applications up to 400 degrees Celsius. For higher temperature, superalloy is extensively used in rocket components, nuclear reactors, and gas turbine engines. IN718 is the most popular nickel base superalloy. This alloy is a $\mathrm{Ni}-\mathrm{Cr}$ alloy being precipitation hardenable and retains excellent mechanical and chemical properties at high temperatures to about 650 degrees Celsius. However, this alloy is a difficult materials to machine due to its strength, abrasiveness, low thermal conductivity, and especially tendency to work harden. Since work hardening occurs when a tool makes a cut, the machined surface of the component is deformed slightly during the cut, leaving it harder than the original material. Due to the extremely high cost of machining and repairing such components, the joining of IN718 has been of a major interest to the aerospace industries, and a considerable amount of research is carried out in this field[1,2].

The present work is concerned with blow forming of sandwich structures with welded sheets of titanium and Inconel. The inner cores were manufactured from diffusion welded sheets for titanium alloy and electron beam welded sheets for IN718. This includes the finite analysis of forming properties of the materials to predict elevated temperature forming behavior of the complex shape of stiffened sandwich structure.

\section{FORMING OF SANDWICH PANEL FROM DIFFUSION WELDED TITANIUM SHEETS}

Diffusion welding process is one of the solid-state pressure welding processes. Diffusion welding is a process by which two surfaces are brought into sufficiently close contact using an applied pressure at elevated temperature to allow bond formation by atomic diffusion across the joint interface. Diffusion welding is an attractive manufacturing method for aerospace applications where mechanical properties in the bond area and a sound metallurgical bond are important. Since diffusion welding is formed from atomic migration across an interface in a solid state, there is no metallurgical discontinuity at the interface and hence mechanical properties and microstructure at the welded region are not different from those 
of the base metal. It shows flexible design capabilities for near net shape forming of complex contoured structures in combination with blow forming technology. It is known that titanium alloys can be joined by diffusion welding without liquid or other secondary materials, due to its ability to dissolve its own oxide in high temperature vacuum[3]. Diffusion welding consisted of initial creep, which is then followed by vacancy diffusion to allow for complete void closure and complete welding across the joint interface[4].

The diffusion welding was conducted in the conventional furnace with inert gas purging with hydrostatic compressive pressure. After applying stop-off material to both surfaces of the core sheets on template region, the multiple sheets were carefully mounted in a fixture. Fixture made with a corrosion resistant high alloy steel was designed to allow hydrostatic gas pressurization at both side of the specimen as shown in Figure 1. The fixture assembly is placed in the furnace with ceramic heaters and welding is conducted in inert environment after uniform temperature has been achieved throughout. Since this tool needs a gas pressure for manufacturing a pressure welding product, it is required to sustain the sealing condition at high temperature and high pressure as shown in Figure 1b. In the method of manufacturing a structural part through pressure welding of multi-sheet metal according to the present embodiment, a complicate shaped heat resisting structure may be manufactured by changing the shape of the insert.

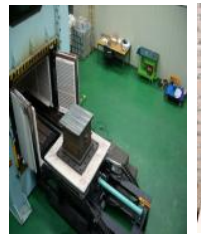

(a)

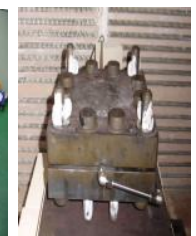

(b)
FIGURE I.(A) FURNACE FOR DIFFUSION WELDING AND (B) FORMING FIXTURE PREPARED IN THE FURNACE.

The diffusion bonded sheet was discretized by 4-node quadrilateral element which has axi-symmetric solid property, and upper and lower die were treated as rigid body. Forming gas pressure was imposed on the lower and upper surface of a core sheet. After diffusion bonding 3 sheets at $4 \mathrm{MPa}$ at $875^{\circ} \mathrm{C}$ for one hour, the gas pressure inside of the middle sheets was increased and the maximum forming pressure was limited to $40 \mathrm{bar}$. The incremental configuration from FEM analysis during blow forming is shown on Figure 2[5].

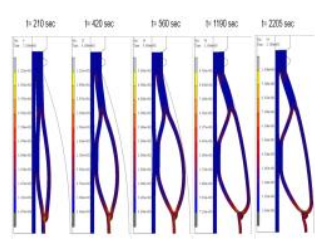

(a)

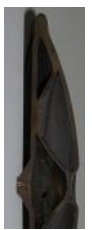

(b)

\section{FORMING OF SANDWICH CYLINDER FROM ELECTRON BEAM WELDED IN718 SHEETS}

IN718 sheet with grain size of about 5 micron was tested for forming parameters and the optimum forming condition was a strain rate of $5 \times 10-4 / \mathrm{sec}$ at $980^{\circ} \mathrm{C}[6]$. After careful investigation to choose the efficient welding method, electron beam welding(EBW) was executed with focusing current of $14.6 \mathrm{~mA}$ and welding current of $6 \mathrm{~mA}$. Diffusion welding was also considered, but its weld strength was too low to accommodate the hydrostatic pressure in order to maintain the core cell shape without proper heat treatment. This is because diffusion welding requires exposure of material at high temperature for relatively long time so that the grain growth is inevitable. Using EBW was not satisfactory during the elevated blow forming process for a single pass of welding. As shown in Figure $3 \mathrm{a}$, structural debonding of weld line is obtained during blow forming process. The problem of debonding is solved by strengthening the weld line with a triple pass so that the welded region was strong enough to maintain the inner core shape(Figure $3 b$ ) during elevated forming process.

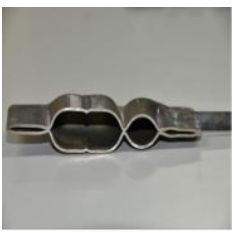

(a)

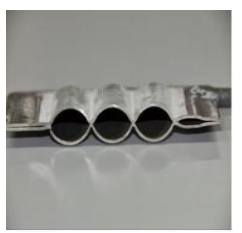

(b)
FIGURE III. PHOTOGRAPHS OF CROSS-SECTIONAL VIEW OF BLOW FORMED IN718 SPECIMENS OF (A)WELDED WITH A SINGLE PASS AND (B)WELDED WITH A TRIPLE PASS[5].

Since the forming temperature is high, the fixtures are fabricated with refractory castable ceramic material as shown in Figure 4. The maximum service temperature of this fixture is $1080^{\circ} \mathrm{C}$. By applying gas pressure, the inner core cells were formed. The pressure increases with maintaining the strain rate range of 1 to $5 \times 10-4 / \mathrm{sec}$ in the early stage and is kept to be constant after reaching the maximum pressure limit of $6 \mathrm{MPa}$. Total pressurizing time is 3.5 hours. Figure $5 \mathrm{a}$ is a photograph of the welded specimen ready for blow forming and Figure $5 \mathrm{~b}$ is a cross- sectional view of sandwich cylinder after blow forming.

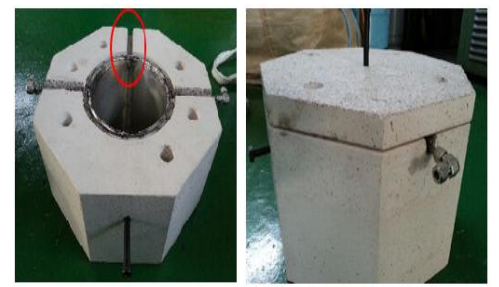

FIGURE IV. PHOTOGRAPHS OF FIXTURES AND PRE-WELDED SPECIMEN FOR SANDWICH CYLINDER.

FIGURE II. . (A)RESULTS OF FEM ANALYSIS AND (B)CROSS SECTIONAL VIEW OF THE FORMED ARTICLE FOR BLOW FORMING OF PRE-BONDED TITANIUM SHEETS[5]. 


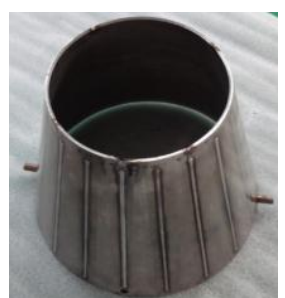

(a)

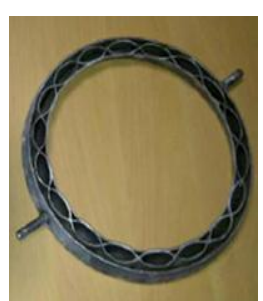

(b)

FIGURE V. PHOTOGRAPHS OF (A) EBW WELDED SPECIMEN BEFORE BLOW FORMING AND (B) CROSS-SECTION VIEW OF SANDWICH CYLINDER AFTER BLOW FORMING.

\section{SUMMARY}

In the present study, superplastic blow forming technology has been successfully applied to manufacture lightweight sandwich structures from pre-welded sheets of titanium and superalloy. For Ti6Al4V, the inner sheets were diffusion welded, while the inner sheets of IN718 were electron beam welded. It is shown that the blow forming process with high temperature materials can be applied to manufacturing of stiffened sandwich structure for aerospace application. In addition, forming profile was developed with FEM analysis and high temperature ceramic fixture was fabricated for service temperature up to $1080^{\circ} \mathrm{C}$ and $6 \mathrm{MPa}$.

\section{REFERENCES}

[1] Jewett, R. P. and Halchak, J. A., in Superalloys 718, 625 and Various Derivatives, ed. E. A. Loria, p.749, TMS, Warrendale, PA (1991).

[2] Roamer, P., Van Tyne, C.J., Matlock, D.K., Meier, A.M., Ruble, H. and Suarez, F., in Superalloys 718, 625, 706 and Various Derivatives, Proceeding of 4th International Symposium, Pittsburgh, PA, June 15-18, 1997, Warrendale, PA. TMS (1997), p. 315-329.

[3] Usacheva, L. V., Svarochnoe Proizvodstvo, 57(2004), p. 11-15.

[4] Lee, H. S., Yoon, J. H. and Cho, W. H., Advanced Materials Research, 228 (2011), p. 666 671.

[5] Lee, H. S., Yoon, J. H. and Yoo, J. T., Inżynieria Materiałowa 35(2014) pp.166-170.

[6] Lee, H. S., Yoon, J. H. and Yoo, J. T., Advanced Materials Research, 430 (2012), p. 539 542. 